\title{
The colour of money: earnings differentials among ethnic groups in Canada
}

\author{
KRISHNA PENDAKUR Simon Fraser University \\ RAVI PENDAKUR Multiculturalism, Department of \\ Canadian Heritage
}

\begin{abstract}
The literature on ethnically based earnings differentials in Canada has focused on differences either between whites and visible minorities or between particular ethnic groups. In this paper we examine both earnings differentials between whites and visible minorities, and earnings differentials within the white and visible-minority groupings. Among both men and women we find substantial earnings differentials both between and within the white and visible-minority groupings. Differentials between whites and visible minorities suggest that the visible-minority category is a useful indicator of economic discrimination. Differentials within these groupings, however, suggest that it is only a rough indicator.
\end{abstract}

La couleur de l'argent: différentiels de revenus entre groupes ethniques au Canada. Les travaux sur les différentiels de revenus entre groupes ethniques au Canada ont porté sur les différences soit entre les Blancs et les minorités visibles soit entre certains groupes ethniques particuliers. Dans ce mémoire, les auteurs examinent à la fois les différentiels de gains entre Blancs et minorités visibles, et ceux à l'intérieur des groupes de Blancs et de minorités visibles. Pour les hommes et les femmes, il existe des différentiels substantiels de gains à la fois entre les groupes de Blancs et de minorités visibles et à l'intérieur de ces groupes. Les différentiels entre Blancs et minorités visibles suggèrent que cette catégorisation est un indicateur utile de discrimination. Cependant, les différentiels à l'intérieur des groupes montrent que c'est seulement un indicateur assez grossier.

\section{Introduction}

In Canada, the Charter of Rights and Freedoms (Canada 1996) mandates, the Abella Royal Commission Report (1984) insists, and the Employment Equity Act (Canada

\footnotetext{
We acknowledge the financial support of the Vancouver Centre of Excellence for Research on Immigrants and Integration the Metropolis and the President's Research Grant Fund of Simon Fraser University. We would like to thank our friends and colleagues for their thoughts and ideas on this work: Tracy Borders, Greg Dow, Curt Eaton, Diane Eaton, Steve Easton, Dennis Forcese, Jane Friesen, Mark Kamstra, Fernando Mata, Judith Moe, Clyde Reed, Chris Ryal, and John Wald. We also thank two anonymous referees for detailed comments. Any mistakes that remain are, of course, our own.
}

Canadian Journal of Economics Revue canadienne d'Economique, Vol. 31, No. 3

August / août 1998. Printed in Canada Imprimé au Canada

0008-4085 / $98 / 518-548 \$ 1.50{ }^{\odot}$ Canadian Economics Association 
1997) requires that a person's ethnic heritage should not constrain his or her labour market opportunity. Although there is a long history of research assessing whether this vision accurately reflects American labour markets, until recently, there has been comparatively little such research about Canada. However in the past five years, a surge of research has documented the existence and size of earnings and wage disparities among ethnic groups in Canada (Howland and Sakellariou 1993; Christofides and Swidinsky 1994; Stelcner and Kyriazis 1995; Baker and Benjamin 1997). These studies find earnings and wage differentials among ethnic groups that cannot be attributed to differences in observable individual characteristics such as age and education. Although suitably cautious, these authors conclude that discrimination may play a negative role for some ethnic groups.

In this paper we examine earnings differentials across ethnic groups in the context of the white/visible-minority ${ }^{1}$ distinction. This distinction is entrenched in Canadian law-with respect to discrimination against ethnic groups, Canadian public policy focuses on discrimination against visible minorities rather than on discrimination against specific ethnic groups. In this paper, we seek to assess the usefulness of the white/visible-minority distinction by evaluating ethnically based earnings differences in the context of the white and visible-minority aggregates. In particular, we explore the degree to which the white versus visible-minority classification system hides ethnically based differences within these aggregate groups.

Contemporary research certainly has addressed the issues of ethnically based labour market discrimination, but in doing so, it has tended to focus on the white/visible-minority categorization, or has examined specific ethnic groups without relating them fully to the overall white/visible-minority division. Christofides and Swidinsky (1994) use the 1989 Labour Market Activity Survey (LMAS) to examine wage differences between white and visible-minority workers. Although they find significant wage differentials between these two groups, they do not explore ethnically based earnings differences within the white and visible-minority aggregate categories. Other authors focus on individual ethnic groups, but do not examine the aggregate categories that underlie the policy debate. Stelcner and Kyriazis (1995) use 1981 Census data to examine earnings differences across two visible-minority and fourteen white ethnic groups, Howland and Sakellariou (1993) use 1986 Census data to examine earnings differences across three visible-minority ethnic groups, and Baker and Benjamin (1997) use 1991 Census data to examine earnings differences across four visible-minority ethnic groups. All these authors find significant earnings differences across their chosen ethnic groups.

Our analysis extends this research in four specific ways. First, the three studies that focus on individual ethnic groups do not examine the visible-minority aggregate as a whole, and the groups that they have chosen to study do not comprise all of the groups that make up the visible-minority aggregate. Second, both Howland

\footnotetext{
1 For the purposes of this paper, an individual is defined as 'white' if his ethnic origins are all European or American (and not Aboriginal); as 'visible minority' if any of his ethnic origins are non-European (and none are Aboriginal); and as 'Aboriginal' if any of his ethnic origins are Aboriginal.
} 
and Sakellariou (1993) and Baker and Benjamin (1997) do not examine any of the ethnic groups that make up the white aggregate category. Third, none of these papers examines differences between people who claim only one ethnic origin and people who claim multiple ethnic origins. Fourth, although Baker and Benjamin (1997) use the largest and most recent data set, they do not analyse ethnically based earnings differences among women. We address all of these issues.

We use data from the 1991 Census Public Use Microdata File (PUMF) to examine earnings gaps both between the white and visible-minority aggregate categories and within these categories. Because immigration status has well-known connections with earnings outcomes, we consider Canadian-born and immigrant workers as distinct groups. We first evaluate earnings differences among male and female workers in five aggregate categories: (1) Canadian-born white; (2) Canadianborn visible minority; (3) Aboriginal; (4) Immigrant white; and (5) Immigrant visible minority. Considering groups (1), (2), and (3), we find that, conditional on observable characteristics, Canadian-born visible-minority men face an earnings gap of 8 per cent and Aboriginal men a gap of 13 per cent, in comparison with Canadian-born white men. Considering groups (1), (4), and (5), we find that immigrant white men and immigrant visible-minority men face earnings gaps of 2 per cent and 16 per cent, respectively, in comparison with Canadian-born white men.

We find quite different results for women. Canadian-born visible minority women face no earnings gap in comparison with Canadian-born white women. In contrast, Aboriginal women face an earnings gap of 7 per cent in comparison with Canadian-born white women. Turning to immigrant women, we find that immigrant white women and immigrant visible-minority women face earnings gaps of 1 per cent and 9 per cent, respectively, in comparison with Canadian-born white women. Our findings for aggregate groups are consistent with and reinforce Christofides and Swidinsky's (1994) analysis of wage differentials based on the 1989 LMAS. $^{2}, 3$ The significant earnings gaps we observe between white and visible-minority workers suggest that, especially for men, visible-minority status may be a useful indicator of economic discrimination.

We also evaluate earnings differentials for men and women within the aggregate categories. Within the Canadian-born white aggregate category we examine earnings differentials among fifteen single- and five multiple-origin ethnic groups. Within the Canadian-born visible-minority aggregate category we examine nine single- and seven multiple-origin ethnic groups, and within the Aboriginal aggregate category we examine one single- and two multiple-origin ethnic groups. We also examine corresponding groups for the immigrant aggregate categories. We find

2 Christofides and Swidinsky (1994) evaluate wage differences rather than earnings differences and find an unexplained wage gap between Canadian-born white and visible-minority workers of 6-8 per cent for men and 3 per cent for women. The strength of their conclusions was hampered by the small numbers of Canadian-born visible minorities in LMAS.

3 The large number of working-age Canadian-born visible minorities in the 1991 Census PUMF provides two advantages over earlier Census data and over the LMAS: (1) it permits the identification of differentials due to visible-minority status as distinct from those due to immigration status; and (2) it permits separate estimates for Montreal, Toronto, and Vancouver. 
wide variation in the earnings gaps faced by both different ethnic groups within the two white aggregates and different ethnic groups within the two visible-minority aggregates. For example, among Canadian-born white men, Greek- and Balkanorigin men face earnings gaps of over 10 per cent in comparison with British-origin men. As for visible-minority ethnic groups, our estimates are similar to those of Baker and Benjamin (1997). For example, among Canadian-born men, Black- and Chinese-origin men face earnings gaps of 17 per cent and 13 per cent, respectively, in comparison with British-origin men. Aboriginal single-origin men face an earnings gap of 23 per cent in comparison with Canadian-born British-origin men. Our results for immigrant men are similar: immigrant white men and immigrant visible minority men are characterized by great within-group heterogeneity.

Our analysis of womens' earnings finds a different pattern. ${ }^{4}$ Among Canadianborn single-origin women, only Greek- and Aboriginal-origin women face large and significant earnings gaps in comparison with British-origin women. In particular, among Canadian-born women, women in the nine visible-minority ethnic groups do not face statistically significant earnings gaps in comparison with British-origin women. Among immigrant women, we find more within-group heterogeneity. Although immigrant Black, Vietnamese, and West Asian women face earnings differentials of more than 10 per cent in comparison with Canadian-born British-origin women, immigrant women of other visible minority ethnic groups do not face large earnings differentials in comparison with Canadian-born British-origin women.

In our sample, approximately one-quarter of the observations fall into our multiple-origin categories. Because more children than adults are multiple origin (1991 Census PUMF), including multiple-origin people in the analysis of discrimination is increasingly important. We find that some multiple-origin workers may face earnings gaps, but only if one or more of their ethnic origins is a visibleminority or Aboriginal ethnic group. In particular, some immigrant visible minority multiple-origin men face earnings differentials of more than 15 per cent in comparison with Canadian-born British-origin men. Similarly, some immigrant visible minority multiple-origin women face earnings differentials of more than 10 per cent in comparison with Canadian-born British-origin women.

Although our results reinforce previous findings from earlier data and suggest that the white/visible-minority distinction does correlate with ethnically based earnings differentials, we also find large unexplained differences in earnings among ethnic groups within the white and visible-minority aggregate categories. This suggests that the visible-minority category is an imperfect indicator of economic discrimination.

\section{Methodology}

Our analysis is divided into two parts. First, we examine earnings differentials between whites, visible minorities, and Aboriginals. Second, we refine this analysis 


\section{Krishna Pendakur and Ravi Pendakur}

by looking at earnings differentials among subgroups of these three basic categories and across cities. Our data are derived from the 1991 PUMF for individuals. This is a 3 per cent sample of the Canadian population.

The basic independent variable used in this paper is 'visible-minority status' as per the employment equity definition. ${ }^{5}$ We use the visible-minority flag and the Aboriginal ethnic origin flag to define every individual as either white, visible minority, or Aboriginal. We define as 'white' all people who report only European, Australian, American, or Canadian ${ }^{6}$ ethnic origins. We define as 'visible minority' all people who report any ethnic origins that are not captured in the white group and who do not report an Aboriginal ethnic origin. We define as 'Aboriginal' all people who report any Aboriginal ethnic origins. These three mutually exclusive aggregate ethnic categories include people who report multiple ethnic origins. We also separate persons born in Canada from immigrants. We are left with three exclusive categories of Canadian-born individuals ${ }^{7}$ (white, visible minority, and Aboriginal) and two exclusive categories of immigrants individuals (white and visible minority). In the latter part of the paper, we break these five basic groups into seventy-eight detailed ethnicity/immigration status categories.

The basic dependent variable in this paper is earnings from wages and salaries. The wage labour market is the largest sector of Canada's labour force, comprising 87 per cent of all working men and 93 per cent of working women age 20 to 64 (1991 Census PUMF). Because visible minorities are more likely to be selfemployed than whites, however, our analysis has the potential to overestimate earnings gaps among visible minority groups if there is a propensity for highly motivated (or high earnings) workers to enter the self-employed sector.

The data frame for our empirical work is permanent residents of Canada, age 20 to 64, not in school full time, living in provinces outside the Atlantic region $^{8}$ (Quebec and west) whose primary source of income was from wage labour sources. ${ }^{9,10}$ That we run regressions on only the employed population suggests that

5 Under Employment Equity legislation, a person is defined as a member of a visible minority if $\mathrm{s} /$ he is neither Aboriginal nor Caucasian in race and non-white in colour. In the public use file of the Census, the visible-minority variable is imputed to be a combination of ethnic origin, place of birth, and mother tongue. Operationally, the visible-minority variable is flagged for persons who are entirely non-aboriginal and non-European in ancestral origin.

6 'Canadian' ethnic origin is reported by approximately 10 per cent of the sample. These cases are classified as 'white.'

7 Our Canadian-born category includes all people born in Canada plus people who are Canadian by birth but were born abroad (that is, Canadian citizens born of Canadian nationals in other countries). All Aboriginals are classified as Canadian born in the regressions involving aggregate ethnic categories. As shown in appendix table A1, approximately 98 per cent of people reporting Aboriginal ethnic origin are born in Canada.

8 We exclude residents of the Territories, Nova Scotia, New Brunswick, Prince Edward Island, and Newfoundland because detailed ethnicity codes are masked in the Atlantic region and in the Yukon and Northwest Territories.

9 Non-permanent residents include refugee claimants and people admitted to Canada on work permits, ministerial permits, or foreign student visas. They are excluded from our analysis because it is impossible to differentiate between the subgroups, each of which has a very different earnings pattern and only some of whose members are legally able to work in Canada.

10 We further refined our target sample by excluding all people who did not report an education 
a selection problem may bias our results, but work by Miller (1987) on the gender wage gap in Canada suggests that correcting for sample selection bias increases the estimate of the gender gap in the offered wage distribution. Miller found that the size of the unexplained portion of the offered wage gap is much bigger than that in the observed wage distribution, so that correcting for selection bias made the estimated discrimination problem more severe. ${ }^{11}$

We ran separate regressions for Census Metropolitan Area (CMA) residents and for non-CMA residents, because we did not want to assume that earnings profiles are the same for these groups. Because the results for non-CMA residents are based on very low counts for some ethnic groups, however, we focus on CMA residents for most of the analysis. The sample is split by sex, with separate regressions for men and for women. Our comparisons are restricted to those within, rather than across, genders. The dependent variable in all regressions is the natural $\log$ of individual earnings from wage labour sources. ${ }^{12}$

Along with dummies for the ethnic categories detailed above, we include as independent variables dummies for full time/part time status (two categories), weeks worked in 1990 (twelve categories), CMA (eighteen cities) or province (six nonAtlantic provinces), household type (eight categories), occupation (sixteen categories), industry (sixteen categories), schooling (fifteen categories), and knowledge of English and French (four categories).

We include continuous measures (and their squares) of potential labour market experience in Canada and in six regions outside Canada for immigrants. Potential labour market experience in Canada is equal to either 'years since completion of schooling' or 'years since immigration,' whichever is less. Obviously, for Canadianborn persons, it is just equal to years since completion of schooling. Potential labour market experience outside Canada (for immigrants only) is separated into six regions of birth (US/UK, Central Europe, Southern Europe, Other Europe, Asia/Africa, and Other) and is equal to years between completion of schooling and immigration to Canada. All potential experience variables are imputations in that we estimate how much labour market experience individuals could have given their age and highest level of schooling. In sections 3.2 and onward, we also include imputed dummy variables for immigrant place of schooling.

level, a household type, an occupation, or an industry. We also dropped all persons who immigrated to Canada during 1990 or 1991, because their reported income data are incomplete (1991 immigrant incomes are zeroed and 1990 immigrants show part-year earnings in the Public Use Sample income data).

11 On the other hand, George and Kuhn (1994) found that correcting for sample selection in the estimation of Aboriginal-white differentials in Canada reduces the size of estimated differentials by about one-third. However, it did not change the pattern of gaps.

12 The loglinear specification is used both in deference to Mincer's (1974) model of the returns to human capital, and because in evaluating earnings disparities across groups not assumed to be productively different, it seems more natural a priori to assume percentage earnings differentials rather than fixed dollar differences. We ran Box-Cox specification tests on the pure linear and pure loglinear forms, but both pure forms were rejected. Thus, the loglinear form may not be worse than the linear form. 
524 Krishna Pendakur and Ravi Pendakur

\section{Results}

Table 1 shows mean earnings, log of earnings and the difference in log of earnings for whites, visible minorities, and Aboriginals by sex, immigration status, and CMA residence status for all persons living in provinces outside the Atlantic region. ${ }^{13}$ Differences are given in comparison with Canadian-born whites for both men and women (denoted by 'Comparison'). We see that for those born in Canada, in nonAtlantic provinces, the mean 1990 earnings for visible minority males is just over $\$ 31,000$ as opposed to over $\$ 34,000$ for white men. Among Canadian-born females, visible-minority women show mean earnings that are almost \$2,000 higher than those for white women. Regardless of gender, Aboriginals earn much less than either white or visible-minority workers born in Canada. In the case of immigrant males, the average earnings of immigrant white males is actually higher than those of Canadian-born white males. In contrast, immigrant visible-minority males earn much less than Canadian-born white males. In the same way, although immigrant white women show higher average earnings than Canadian-born white women, immigrant visible-minority women show somewhat lower average earnings than Canadian-born white women.

In non-CMA areas, the overall earnings structure is lower than for all persons, but the earnings pattern is similar. However, there were relatively few visible minorities born in Canada living outside the CMAs. It is thus difficult to conduct any detailed analysis at this level. In the eighteen non-Atlantic CMA regions, the average earnings and the disparities in earnings between visible minorities and whites are higher than is the case for the non-CMA residents. In the CMAs, Canadianborn visible minority men earn almost $\$ 5,000$ less than Canadian-born white men. Immigrant visible-minority men and Aboriginal men earn on average about $\$ 7,000$ less than Canadian-born white men.

The picture for women is somewhat different. For CMA residents, Canadianborn visible minority women and immigrant white women have average earnings roughly equal to the average earnings of Canadian-born white women. In contrast, Aboriginal women and immigrant visible-minority women earn on average \$23,000 less than Canadian-born white women.

\subsection{There are earnings differentials between aggregate groups}

Table 1 shows that there are considerable earnings differentials between whites and visible minorities and that these differentials vary by sample group (CMAs vs. non-CMAs; men vs. women). If we assert that all individual characteristics except for age, sex, and ethnic origin are unconstrained at the individual level, then our work is almost done: but for age, table 1 could be interpreted as revealing true earnings differentials. Some characteristics, however, should be treated as exogenous for the purposes of estimation. To allow for some sensitivity testing, we

13 Means and counts for all the variables used in this paper, as well as detailed regression results for all analyses presented in this paper, are available on request from the authors. 
TABLE 1

Mean earnings and sample counts for selected groups, Canada 1990

\begin{tabular}{|c|c|c|c|c|c|c|}
\hline Sex & $\begin{array}{l}\text { Immigrant } \\
\text { status }\end{array}$ & $\begin{array}{l}\text { Employment } \\
\text { equity status }\end{array}$ & $\begin{array}{l}\text { Mean } \\
\text { earnings (\$) }\end{array}$ & $\begin{array}{l}\text { Log of } \\
\text { earnings }\end{array}$ & $\begin{array}{l}\text { Difference in } \\
\log \text { of } \\
\text { earnings }\end{array}$ & Count \\
\hline \multirow[t]{20}{*}{ MALES } & \multicolumn{6}{|c|}{ All residents: Quebec and West } \\
\hline & \multicolumn{2}{|c|}{ Total } & & $\begin{array}{l}10.18 \\
10.19\end{array}$ & & 144,533 \\
\hline & \multirow{2}{*}{$\begin{array}{l}\text { Canadian- } \\
\text { born }\end{array}$} & White & 34,036 & 10.19 & Comparison & 112,317 \\
\hline & & Visible Minority & $\begin{array}{l}31,318 \\
25,441\end{array}$ & $\begin{array}{r}10.04 \\
074\end{array}$ & $\begin{array}{l}-0.15 \\
-0.45\end{array}$ & $\begin{array}{l}1,366 \\
3,072\end{array}$ \\
\hline & \multirow{2}{*}{ Immigrant } & White & 38,648 & 10.33 & 0.15 & 18,044 \\
\hline & & Visible Minority & 29,814 & 10.01 & -0.18 & 9,734 \\
\hline & \multicolumn{6}{|c|}{ Non-CMA residents: Quebec and West } \\
\hline & \multicolumn{2}{|l|}{ Total } & 30,983 & 10.08 & & 48,977 \\
\hline & \multirow{3}{*}{$\begin{array}{l}\text { Canadian- } \\
\text { born }\end{array}$} & White & 30,915 & 10.09 & Comparison & 42,876 \\
\hline & & Visible Minority & 30,567 & 10.04 & -0.05 & 242 \\
\hline & & Aboriginal & 23,180 & 9.59 & -0.50 & 2,024 \\
\hline & \multirow[t]{2}{*}{ Immigrant } & White & 36,351 & 10.28 & 0.19 & 3,263 \\
\hline & & Visible Minority & 33,141 & 10.10 & 0.02 & 572 \\
\hline & \multicolumn{6}{|c|}{ CMA residents: Quebec and West } \\
\hline & Total & & 35,621 & 10.23 & & 95,556 \\
\hline & \multirow{3}{*}{$\begin{array}{l}\text { Canadian- } \\
\text { born }\end{array}$} & White & 35,984 & 10.25 & Comparison & 69,441 \\
\hline & & Visible Minority & 31,479 & 10.04 & -0.21 & 1,124 \\
\hline & & Aboriginal & 27,951 & 9.90 & -0.35 & 1,048 \\
\hline & \multirow[t]{2}{*}{ Immigrant } & White & 39,169 & 10.34 & 0.10 & 14,781 \\
\hline & & Visible Minority & 29,612 & 10.00 & -0.25 & 9,162 \\
\hline \multirow[t]{21}{*}{ FEMALES } & \multicolumn{6}{|c|}{ All residents: Quebec and West } \\
\hline & \multicolumn{2}{|c|}{ Total } & 20,634 & 9.59 & & 130,598 \\
\hline & Canadian- & White & 20,619 & 9.59 & Comparison & 102,280 \\
\hline & \multirow{2}{*}{ born } & Visible Minority & 22,437 & 9.70 & 0.10 & 1,372 \\
\hline & & Aboriginal & 17,459 & 9.33 & -0.26 & 2,734 \\
\hline & \multirow[t]{2}{*}{ Immigrant } & White & 21,661 & 9.65 & 0.06 & 15,108 \\
\hline & & Visible Minority & 20,123 & 9.60 & 0.00 & 9,104 \\
\hline & \multicolumn{6}{|c|}{ Non-CMA residents: Quebec and West } \\
\hline & Total & & 17,310 & 9.37 & & 41,657 \\
\hline & \multirow{3}{*}{$\begin{array}{l}\text { Canadian- } \\
\text { born }\end{array}$} & White & 17,341 & 9.38 & Comparison & 36,761 \\
\hline & & Visible Minority & 19,324 & 9.51 & 0.13 & 192 \\
\hline & & Aboriginal & 14,623 & 9.11 & -0.27 & 1,653 \\
\hline & \multirow[t]{2}{*}{ Immigrant } & White & 18,581 & 9.44 & 0.06 & 2,610 \\
\hline & & Visible Minority & 16,340 & 9.33 & -0.05 & 441 \\
\hline & \multicolumn{6}{|c|}{ CMA residents: Quebec and West } \\
\hline & \multicolumn{2}{|c|}{ Total } & 22,190 & 9.70 & & 88,941 \\
\hline & \multirow{3}{*}{$\begin{array}{l}\text { Canadian- } \\
\text { born }\end{array}$} & White & 22,482 & 9.71 & Comparison & 65,519 \\
\hline & & Visible Minority & 22,930 & 9.73 & 0.01 & 1,180 \\
\hline & & Aboriginal & 19,925 & 9.52 & -0.19 & 1,081 \\
\hline & \multirow[t]{2}{*}{ Immigrant } & White & 22,326 & 9.70 & -0.02 & 12,498 \\
\hline & & Visible Minority & 20,307 & 9.61 & -0.10 & 8,663 \\
\hline
\end{tabular}

SOURCE: 1991 Public Use Microdata File. Individual file.

NOTES

Population age 20-64 not in school full time, with class of worker equal to wage earner.

Residents of non-Atlantic Canada only. 


\section{Krishna Pendakur and Ravi Pendakur}

use three groups of individual characteristics as controls in our estimation. We define personal characteristics as potential labour market experience (both Canadian and foreign), education, household type, and official language knowledge. Personal characteristics are included in all regressions. We define location as CMA of residence for CMA residents and province of residence for non-CMA residents. We define work characteristics as occupation, industry, full-time/part-time status, and weeks worked. Location and work characteristics are added to the control list in some regressions.

Table 2 shows selected coefficients from regressions of log-earnings on individual characteristics, with separate regressions for men and women. We present several specifications that vary in their sample universe - either all residents, CMA residents, or non-CMA residents - and vary in the control list - either personal characteristics only, personal characteristics and location, or personal characteristics, location, and work characteristics. In regressions 2.1 and 2.6 we estimate log-earnings regressions on all provincial residents outside the Atlantic region, including only personal characteristics as regressors. In regressions, 2.2-2.3 and 2.7-2.8, we split the population into CMA residents, with added location controls for eighteen CMAs, and non-CMA residents, with added location controls for six non-Atlantic provinces, and control for personal characteristics. In regressions 2.4-2.5 and 2.9-2.10, we add work characteristics to the control list. In each regression, the comparison group for log-earnings differentials ${ }^{14}$ is denoted by the word 'comparison.'

Regression 2.1 shows that if we take only personal characteristics as given and do not control for city or province of residence, then there are large ${ }^{15}$ and statistically significant earnings differences between white and visible minority men. In particular, we see an earnings gap of 10.0 per cent between Canadianborn visible-minority and Canadian-born white men, and a gap of 13.9 per cent between immigrant visible-minority and Canadian-born white men. Aboriginal men face an earnings gap of 33.1 per cent in comparison with Canadian-born white men.

Regressions 2.2 and 2.3 show coefficient estimates from separate log earnings

14 In loglinear models, coefficient estimates can be interpreted as revealing the percentage change in the left-hand side variable in response to a small change in the right-hand side variable. In our discussion of results, and in our tables, we treat coefficients as if they reveal approximate percentage differences in earnings over changes in our dummy variables. However, dummy variables cannot change by a small amount; they can change only from zero to one or vice versa. Thus, for large coefficients, the per cent change in earnings is slightly larger than the coefficient estimate. For per cent changes of less than 10 per cent, however, the bias is less than one-half of one percentage point.

15 To say that a coefficient estimate is 'large' is to assert that it is economically significant. The unexplained gender wage gap is approximately 10-12 per cent (Kidd and Shannon 1994) and unexplained interindustry wage differentials push wages away from the average by as much as \pm 20 per cent (Gera and Grenier, 1994); these differences are certainly considered large by social scientists working on discrimination or segmented markets. We treat differentials that are bigger than 5 per cent in absolute value as 'large.' 


\begin{tabular}{|c|c|c|c|c|c|c|c|}
\hline \multirow[b]{3}{*}{ Sex } & \multirow{3}{*}{$\begin{array}{l}\text { Immigrant } \\
\text { status }\end{array}$} & \multirow{3}{*}{$\begin{array}{l}\text { Employment } \\
\text { equity status }\end{array}$} & \multicolumn{5}{|l|}{ Control List } \\
\hline & & & \multirow{2}{*}{$\begin{array}{l}\begin{array}{l}\text { Personal } \\
\text { characteristics }\end{array} \\
\text { All residents }\end{array}$} & \multicolumn{2}{|c|}{$\begin{array}{l}\text { Personal characteristics, } \\
\text { location }\end{array}$} & \multicolumn{2}{|c|}{$\begin{array}{l}\text { Personal characteristics } \\
\text { location, work characteristics }\end{array}$} \\
\hline & & & & Non CMA residents & CMA residents & Non CMA residents & CMA residents \\
\hline \multirow[t]{7}{*}{$M A L E S$} & & & Regression 2.1 & Regression 2.2 & Regression 2.3 & Regression 2.4 & Regression 2.5 \\
\hline & Canadian- & White & Comparison & Comparison & Comparison & Comparison & Comparison \\
\hline & born & Visible Minority & $-10.0 \% *$ & $-10.2 \% *$ & $-13.5 \% *$ & $-4.0 \%$ & $-8.2 \%^{*}$ \\
\hline & & Aboriginal & $-33.1 \% *$ & $-36.2 \% *$ & $-22.4 \% *$ & $-18.8 \% *$ & $-12.5 \% *$ \\
\hline & Immigrant & White & $0.8 \%$ & $0.8 \%$ & $-5.0 \% *$ & $1.9 \%$ & $-2.3 \% *$ \\
\hline & & Visible Minority & $-13.9 \% *$ & $-2.0 \%$ & $-21.5 \% *$ & $-0.8 \%$ & $-15.8 \% *$ \\
\hline & & & $\begin{array}{l}n=144,553 \\
R^{2}=0.187\end{array}$ & $\begin{array}{l}n=48,977 \\
R^{2}=0.163\end{array}$ & $\begin{array}{l}n=95,556 \\
R^{2}=0.209\end{array}$ & $\begin{array}{l}n=48,977 \\
R^{2}=0.403\end{array}$ & $\begin{array}{l}n=95,556 \\
R^{2}=0.437\end{array}$ \\
\hline \multirow[t]{7}{*}{ FEMALE } & & & Regression 2.6 & Regression 2.7 & Regression 2.8 & Regression 2.9 & Regression 2.10 \\
\hline & Canadian- & White & Comparison & Comparison & Comparison & Comparison & Comparison \\
\hline & born & Visible Minority & $8.2 \%$ & $9.2 \%$ & $0.5 \%$ & $9.7 \% * *$ & $0.2 \%$ \\
\hline & & Aboriginal & $-19.8 \% *$ & $-14.9 \% *$ & $-13.4 \% *$ & $-8.9 \% *$ & $-6.8 \% *$ \\
\hline & Immigrant & White & $5.9 \%$ & $1.6 \%$ & $-3.4 \% *$ & $2.8 \%$ & $-1.4 \%$ \\
\hline & & Visible Minority & $5.4 \%$ & $-0.5 \%$ & $-8.3 \% *$ & 6.9 & $-9.1 \%^{*}$ \\
\hline & & & $\begin{array}{l}n=130,598 \\
R^{2}=0.118\end{array}$ & $\begin{array}{l}n=41,657 \\
R^{2}=0.119\end{array}$ & $\begin{array}{l}n=88,941 \\
R^{2}=0.124\end{array}$ & $\begin{array}{l}n=41,657 \\
R^{2}=0.499\end{array}$ & $\begin{array}{l}n=88,941 \\
R^{2}=0.491\end{array}$ \\
\hline
\end{tabular}

SOURCE: 1991 Public Use Microdata File. Individual file.

NOTES

${ }^{*}$ Denotes significance at the 5 per cent level.

${ }^{* *}$ Denotes significance at the 10 per cent level.

All regressions control for personal characteristics: household type, official language knowledge, education, potential experience in Canada, and potential experience in six regions outside Canada.

Regressions 2.4-2.5 and 2.9-2.10 add controls for work characteristics: full/part-time, weeks worked, occupation, and industry.

All residents regressions (2.1 and 2.6) do not control for geograpic area or for work characteristics.

Non-CMA regressions include controls for six non-Atlantic provinces, and CMA regressions include controls for eighteen cities.

Population age 20-64 not in school full time, with class of worker equal to wage earner. Non-Atlantic residents only. 
regressions for urban men and non-urban men. ${ }^{16}$ In these regressions, we control for personal characteristics and location (CMA or province or residence). Among Canadian-born men, we see that the visible-minority/white differentials for nonCMA residents and CMA residents are 10.2 per cent and 13.5 per cent, respectively. This is similar to what we saw in regression 2.1. Turning to immigrant visible minority men, however, we see that the earnings differentials for non-CMA residents and CMA residents are 2.0 per cent and 21.5 per cent, respectively, which is quite different from the results in regression 2.1. Among men, regressions 2.2 and 2.3 show that Aboriginals face earnings differentials of over 20 per cent when we control for personal characteristics and location.

Regressions 2.4 and 2.5 examine the same populations, but add work characteristics to the control list. It is appropriate to add these controls if we presume that work characteristics, such as occupation and industry, are unconstrained at the individual level. Even with these controls added, substantial and significant earnings gaps exist both in the non-CMA and CMA regions. Among non-CMA residents, Canadian-born visible-minority men do not face a statistically significant earnings gap in comparison with Canadian-born white workers. In contrast, among CMA residents, Canadian-born visible minority men face a statistically significant earnings gap of 8.2 per cent. Aboriginal men face earnings penalties of 18.8 per cent and 12.5 per cent among non-CMA residents and CMA residents, respectively. Turning to immigrant men, we see that among non-CMA residents, neither immigrant white men nor immigrant visible-minority men earn significantly less than Canadian-born white men. Among CMA residents, immigrant white men and immigrant visible-minority men face earnings gaps of 2.3 per cent and 15.8 per cent, respectively.

Regressions 2.6 to 2.10 show the same models run for females. Regression 2.6 shows results from a regression that pools all women, both CMA and non-CMA residents, and includes controls only for personal characteristics. Here, we see no statistically significant earnings differentials across white and visible-minority women and a very large earnings gap of 19.8 per cent between Aboriginal women and Canadian-born white women. Regression 2.7 shows that among women in the non-CMA regions Aboriginals face a large earnings gap, but other groups do not.

16 Running separate regressions for urban and non-urban residents and running regressions on only urban residents introduce a possible selection bias into the regressions. In particular, unobserved characteristics that affect labour market outcomes may be correlated with geographic location decisions. We did not pursue a selectivity-bias corrected regression strategy, because the Public Use file of the 1991 Census does not have an instrument that is a priori correlated with choice of urban versus non-urban location but not correlated with potential earnings. For example, ethnocultural variables, such as language, ethnicity, and religion may be correlated with choice of urban versus non-urban location, but also may be correlated with potential earnings. If we assume that selectivity effects are very important, then regressions 2.1 and 2.6 are appropriate in that choice of geographic location is assumed to be fully endogenous, and regression coefficients provide consistent estimates of the direct effect of group membership on earnings plus the indirect effect of group membership on earnings through choice of geographic location. On the other hand, if we assume that selectivity effects are not important, then regressions $2.2-2.5$ and 2.7-2.10 are appropriate in that they include controls for differences across markets and provide consistent estimates of the direct effect of group membership on earnings by itself. 
If we turn to regressions 2.8 and 2.10 , which examine women in the CMAs, it seems that the pattern of earnings differentials is quite different from that of men. Among Canadian-born women in the CMAs, whites and visible minorities earn about the same, regardless of whether or not work characteristics are included.

Other groups of women in the CMAs do face earnings gaps. Immigrant white women earn slightly less than Canadian-born white women (see regressions 2.8 and 2.10 ), but the differential is not statistically significant in the regression controlling for work characteristics. Immigrant visible-minority women living in the CMAs face statistically significant earnings gaps of 8.3 per cent when we control for personal characteristics and 9.1 per cent when we control for both personal and work characteristics. In comparing regressions 2.5 and 2.10, we find two stark differences between the results for men and for women. First, although Canadianborn visible-minority men earn 8.2 per cent less than their white counterparts, Canadian-born visible minority women earn about the same as white Canadianborn women. Second, the differentials faced by Aboriginals and visible-minority immigrants seem to be about twice as large for men as for women.

In the next section we explore one common explanation for immigrant earnings differentials: real or perceived differences in human capital. In this section, we add a set of new variables that impute where immigrants got their educational credentials, and ask whether or not inclusion of these variables eliminates the earnings differentials faced by immigrant visible minorities. Because there are very few Canadian-born visible minorities and immigrant visible minorities outside the CMAs, we restrict the analysis from this point forward to focus on earnings differentials within the CMAs.

\subsection{Visible minority immigrant differentials remain after controlling for place of schooling}

Among educated immigrants, one important reason for an earnings penalty could be non-equivalence or non-recognition of academic credentials (see McDade 1988; daSilva 1992). If professional and technical degrees gained abroad are not recognized or are not equivalent to those gained in Canada, immigrants may face an earnings gap compared with similarly educated workers with Canadian degrees and certificates. If true skills go unrecognized, it may also be that Canada is losing a portion of its effective workforce.

Table 3 examines issues of place of schooling by adding a series of variables which attempt to identify the place and highest level of schooling for immigrants. Table 3, panel A shows selected regression coefficients for a model that includes controls for six regions and four levels of schooling. ${ }^{17}$ These results can be interpreted as showing differentials for residents who have attained their highest level

17 We assume that place of schooling is the same as place of birth for immigrants who arrived after they finished their highest level of schooling. We included twenty-four dummies for each of six regions (US/UK, Southern Europe, Central Europe, Other Europe, Asia/Africa, and Other) interacted with four levels of schooling (Less than High School, High School, Some Post Secondary, and University Degree or more). 
530 Krishna Pendakur and Ravi Pendakur

TABLE 3 PANEL A

Ethnicity immigration status coefficients from log earnings regressions, with added controls for immigrant place/level of schooling

\begin{tabular}{llll}
\hline Sex & Immigrant status & Employment equity status & \\
\hline MALES & & White & Regression 3.1 \\
& Canadian-born & Comparison \\
& & $-8.2 \%^{*}$ \\
& & Aboriginal & $-12.5 \%^{*}$ \\
& Immigrant & White & $-2.6 \%^{*}$ \\
& & Visible Minority & $-16.2 \%^{*}$ \\
& & $n=95,556$ \\
& & $R^{2}=0.437$ \\
FEMALES & & Regression 3.2 \\
& Canadian-born & White & comparison \\
& & Visible Minority & $0.1 \%$ \\
& Immigrant & Aboriginal & $-6.6 \% \%^{*}$ \\
& & White & $-1.1 \%$ \\
& & Visible Minority & $-7.8 \% \%^{*}$ \\
& & & $R^{2}=08,941$ \\
& & & \\
\hline
\end{tabular}

TABLE 3 PANEL B

Place/level of schooling coefficients from log earnings regressions, with added controls for immigrant place/level of schooling

\begin{tabular}{|c|c|c|c|c|c|}
\hline \multirow[b]{2}{*}{ Sex } & \multirow[b]{2}{*}{ Place of education } & \multicolumn{4}{|c|}{ Coefficients on place of education by level of education } \\
\hline & & $\begin{array}{l}\text { Less than high } \\
\text { school }\end{array}$ & High school & $\begin{array}{l}\text { Some post- } \\
\text { secondary }\end{array}$ & $\begin{array}{l}\text { Post-secondary } \\
\text { degree }\end{array}$ \\
\hline \multirow[t]{7}{*}{ MALES } & & \multicolumn{4}{|c|}{ Regression 3.1} \\
\hline & US or UK & $0.6 \%$ & $10.6 \%{ }^{*}$ & $13.2 \% *$ & $13.2 \% *$ \\
\hline & Central Europe & $-1.5 \%$ & $-4.4 \%$ & $-1.1 \%$ & $-13.5 \% *$ \\
\hline & Southern Europe & $5.6 \%$ & $-3.6 \%$ & $-4.3 \%$ & $-4.7 \%$ \\
\hline & Other Europe & $-6.5 \%$ & $2.6 \%$ & $-8.0 \% *$ & $-2.4 \%$ \\
\hline & Asia or Africa & $3.2 \%$ & $0.9 \%$ & $0.9 \%$ & $-2.1 \%$ \\
\hline & Other (inc. Australia) & $6.8 \%$ & $2.1 \%$ & $9.9 \%$ & $10.2 \%{ }^{* *}$ \\
\hline \multirow[t]{7}{*}{ FEMALES } & & \multicolumn{4}{|c|}{ Regression 3.2} \\
\hline & US or UK & $-3.6 \%$ & $-7.8 \%{ }^{* *}$ & $-6.4 \%{ }^{* *}$ & $-7.3 \%{ }^{* *}$ \\
\hline & Central Europe & $4.0 \%$ & $0.5 \%$ & $-4.4 \%$ & $-21.7 \%$ \\
\hline & Southern Europe & $1.6 \%$ & $1.0 \%$ & -9.2 & $8.8 \%$ \\
\hline & Other Europe & $10.0 \% *$ & $8.9 \%{ }^{* *}$ & 4.7 & $-1.0 \%$ \\
\hline & Asia or Africa & $0.0 \%$ & $-1.2 \%$ & $-4.2 \%$ & $-16.4 \% *$ \\
\hline & Other (inc. Australia) & $4.8 \%$ & $-1.7 \%$ & $4.4 \%$ & $-6.4 \%$ \\
\hline
\end{tabular}

SOURCE: 1991 Public Use Microdata File. Individual file.

NOTES

${ }^{*}$ Denotes significance at the 5 per cent level.

${ }^{* *}$ Denotes significance at the 10 per cent level.

All regressions control for personal characteristics: household type, official language knowledge, education, potential experience in Canada, and potential experience in six regions outside Canada.

All regressions include controls for work characteristics: full/part-time, weeks worked, occupation, and industry.

All regressions include twenty-four foreign place of schooling variables (four levels by six regions of birth).

Population age 20-64 not in school full time, with class of worker equal to wage earner. Non-Atlantic CMA residents only. 
of schooling in Canada. All Canadian-born residents are assumed to have attained their highest level of schooling in Canada. For immigrants who are imputed to have received their highest level of schooling outside Canada, Table 3, panel B shows additional differentials. In this model, we identify regions from which educational credentials are likely rewarded and those from which they are not. We can also ask whether immigrant earnings gaps disappear when we control for differences in place of education.

The estimates in regression 3.1 presented in table 3, panel A show that adding place of schooling to the control list does not much change the estimated earnings gap for immigrant males. When regression 3.1 is compared with regression 2.5 , the earnings gaps for immigrant men remain approximately 2 per cent for white immigrants and 16 per cent for visible-minority immigrants. The table also shows, however, that there are large differences in the returns to schooling both by where schooling was received and by level of schooling. Among men, immigrants from the United Kingdom or United States who finished their schooling before arriving in Canada earn significantly more than similar immigrants who finished their schooling in Canada. Immigrant males who completed degrees in Central Europe, however, may expect a 13.5 per cent penalty compared with those who finished their schooling in Canada. Men who received at least some post-secondary schooling in 'other Europe' (which includes Northern Europe) can expect an 8.0 per cent penalty. However, there are no statistically significant earnings differentials for immigrants who finished their schooling in Southern Europe or Asia/Africa. Thus, even though some immigrant men who were educated outside Canada may earn more or less than immigrant men who were educated in Canada, this difference in the return to human capital does not explain away the earnings gaps faced by either white or visible-minority immigrants. In particular, an immigrant visible-minority man who completed his education in Canada may expect to earn 16.2 per cent less than a Canadian-born white man, even though both have Canadian education.

For women, the inclusion of place/level of schooling variables does change the pattern of earnings differentials. Although including controls for place of education does not change the estimated earnings differentials for immigrant white women, it does affect the estimated differential for immigrant visible-minority women. The earnings gap for immigrant visible minority women drops by 1.3 percentage points when place/level of schooling variables are included, from 9.1 per cent in regression 2.10 to 7.8 per cent in regression 3.2 (this difference is statistically significant at the 10 per cent level). This suggests that place of schooling may account for some of the earnings differentials between visible-minority immigrant women and Canadian-born white women. Inclusion of place/level of schooling, however, does not drive the estimated earnings differential for visible-minority immigrant women to zero, or even down to the level of that for white immigrant women.

Looking now at the place of schooling estimates shown in table 3, panel B, we observe that among immigrant women who completed their education outside Canada, women with more education face large additional earnings differentials, but less educated women do not. Compared with the results for men, women who 


\section{Krishna Pendakur and Ravi Pendakur}

completed their education in the United Kingdom or the United States get smaller place-of-schooling earnings bonuses. Further, we see that women who completed degrees in Asia or Africa face an earnings penalty of 16.4 per cent in comparison to those educated in Canada. For those with degrees from Central Europe, the estimated earnings difference is 21.7 per cent.

There are a number of rationales for why place of schooling may effect earnings, and why women may be more affected than males. First, it is possible that the quality of human capital acquired in Canada, the United States, or the United Kingdom is higher than that acquired elsewhere. Thus, employers may pay some immigrants less because a Master of Arts degree gained in Central Europe is less productive than one earned in Canada. Second, it is possible that even if credentials are productively identical, employers have no way of recognizing their relative worth. Third, professional organizations may simply refuse to recognize and grant membership to immigrants with foreign credentials in order to protect their market power.

A fourth explanation is that we may be confusing an immigration-policy-based selection problem among female immigrants with a human capital problem. Given that the head of a prospective immigrating family is likely to be male, men are more likely to be screened for occupational suitability and job readiness than is the case for women. Primary applicants in occupations that are in short supply or who have jobs prearranged in Canada are given preference in the immigrant intake; primary applicants are, in effect, prescreened. They are more likely to enter Canada with jobs ready for them, and thus with recognized and rewarded credentials. It is likely that women more often come in as part of the accompanying family (rather than as the primary applicant) and are not screened on the basis of educational qualifications. They are therefore more susceptible to losing their human capital or not getting its full return.

Although we find large and statistically significant earnings differences between those immigrants who completed their education in Canada and those immigrants who completed their education abroad, we find that immigrant earnings gaps remain even after place of education is added to the control list. In particular, even when we include controls for personal characteristics, location, work characteristics, and place of education, immigrant visible-minority men and women face earnings gaps of 16.2 per cent and 7.8 per cent, respectively, in comparison with Canadian-born white workers.

\subsection{Earnings gaps are not fully explained by characteristics}

In sections 3.1 and 3.2, we found large and statistically significant earnings gaps between our aggregate ethnicity/immigration groups. It is natural to ask if these differentials are dependent on our specification that earnings differences come in as a single dummy variable for each group. In this section, we use a more general specification, allowing a separate earnings equation for each of the five groups. Using this more general specification, we ask whether differences in average log earnings across groups are due to differences in individual characteristics. 
Table 4 shows the results of Oaxaca decompositions of the differences in mean $\log$ earnings across groups. Column A shows the mean log earnings for each group (these data are also shown in table 1, CMA residents only). Column B shows the mean log earnings of each group, if the returns to characteristics were given by a single non-discriminatory earnings profile for all groups. Following Cotton (1988), we define this hypothetical non-discriminatory earnings profile as the weighted average of the group-specific earnings profiles, with weights being equal to population proportions.

Column $\mathrm{C}$ shows the difference in each group's mean log earnings and the comparison group's mean log earnings evaluated on the non-discriminatory earnings profile. Thus, Column $\mathrm{C}$ is a measure of mean log earnings difference due to characteristics. Column D shows the difference between each group's mean log earnings (using that group's actual earnings profile) and that group's mean log earnings on the non-discriminatory earnings profile. Since characteristics are held constant, this difference can be interpreted as a measure of discrimination if negative, or privilege if positive. Finally, Column E shows the difference between each group's privilege or discrimination and the comparison group's privilege or discrimination, which measures the advantage of the comparison group over the other groups. In all cases, the comparison group is Canadian-born white.

Looking first at Canadian-born males, we see from columns $\mathrm{C}$ and $\mathrm{E}$ that the 0.208 gap in average log earnings between whites and visible minorities can be decomposed into 0.124 log earnings points due to characteristics, such as age and education level, and $0.083 \mathrm{log}$ earnings points due to privilege and discrimination (Canadian-born white advantage). Similarly, although two-thirds of the 0.348 average log earnings gap between Aboriginal and Canadian-born white men can be explained by characteristics, 0.126 log earnings points can be interpreted as due to the advantage of Canadian-born white men over Aboriginal men.

Turning to the results for women, we find that the very small differences in average log earnings between Canadian-born visible-minority and Canadian-born white women may be decomposed into a small component due to characteristics and a small component due to Canadian-born white advantage. In contrast, the 0.190 difference in average log earnings between Aboriginal women and Canadian-born white women can be decomposed into $0.123 \mathrm{log}$ earnings points due to characteristics and $0.067 \log$ earnings points due to Canadian-born white advantage. The 0.105 difference in average log earnings between immigrant visible-minority women and Canadian-born white women can be decomposed into 0.019 log earnings points due to characteristics and $0.086 \log$ earnings points due to Canadian-born white advantage.

Comparing these results with those given in table 2, regressions 2.5 and 2.10, we see that the estimated differentials in the linear model are very similar to the estimates of Canadian-born white advantage shown in table 4. Using a more general empirical model that allows for different earnings profiles across groups does not change our conclusions about the size and patterns of earnings differentials. 


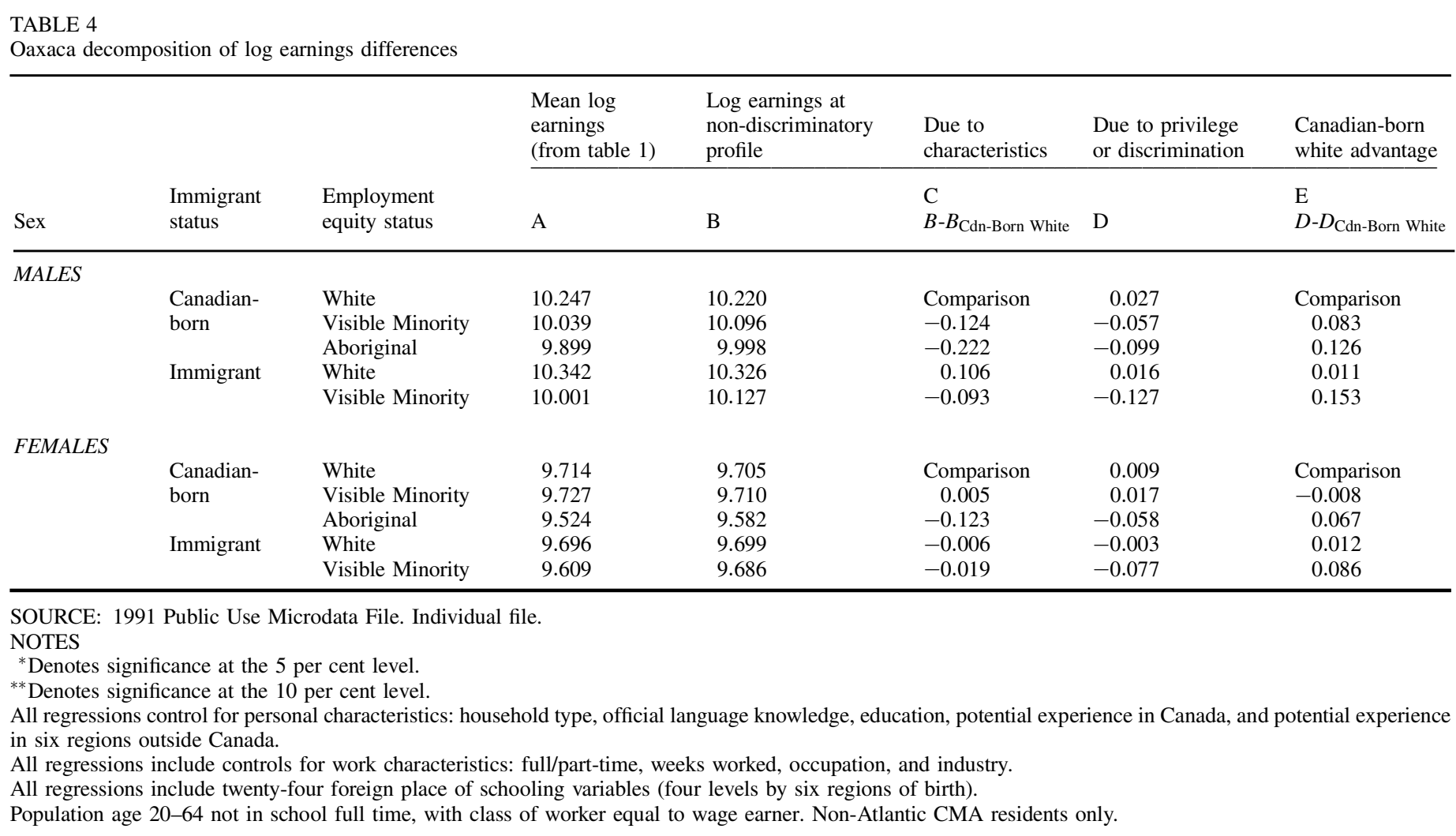




\subsection{Earnings differ within aggregate groups}

Up to this point, each of the five groups has been treated as an homogeneous entity. However, each group has within it the possibility for a great deal of heterogeneity. The visible-minority aggregate category, for example, is a construct composed of nine distinct ethnic groups, which include, among others, persons of Asian, Central American, and African descent. Similarly, the white aggregate category comprises many distinct, largely European, ethnic groups.

One might ask how much variance is hidden within the five group model used thus far. ${ }^{18}$ We address this issue by identifying seventy-eight detailed ethnicity/immigration status groups (we define thirty-nine single- and multiple-origin ethnic groups by two immigration status groups) and estimating earnings differentials across these groups. To begin, the amount of within-group heterogeneity can be assessed by looking at the amount of variance explained in a regression of mean earnings by detailed ethnicity/immigration status group on the our five aggregate category dummies, plus an intercept. We find that the five basic group dummies do not explain a great deal of the variance in these data; for men, the basic groups explain 17 per cent of the variance in mean earnings across the seventy-eight detailed groups, and for women, the basic groups explain 25 per cent of the variance in mean earnings across the seventy-eight detailed groups. That the aggregate categories explain only a small fraction of intergroup earnings differences across ethnicities suggests that the visible-minority employment equity category may be a fairly blunt instrument. We explore this possibility by estimating log-earnings regressions with our seventy-eight detailed ethnicity/immigration status indicators.

Table 5 shows earnings differentials for our detailed groups (table A1 shows the mean earnings and counts for these detailed ethnicity/immigration groups). Persons who report a single ethnic origin are identified in one of fifty categories of ethnicity/immigration class: twenty-five Canadian born and twenty-five immigrant origins. These twenty-five single origins comprise fifteen white origins, nine visible-minority origins, and one Aboriginal origin. Persons who report several ethnic origins (multiple-origin persons) are coded somewhat differently. To deal with multiple origins, we collapsed the twenty-five single-origin categories into seven groups: British, French, Southern European, Central European, Other European, Visible Minority, and Aboriginal. We then separate multiple-origin respondents into those who report a visible-minority ethnic origin from those who did not. Finally, we separate Canadian-born multiple-origin cases from immigrant multiple-origin cases, giving us a total of twenty-eight multiple-origin variables (seven multiple-origin groups interacted with visible minority status and immigration status). Although the single-origin ethnicity variables are dummy variables, the multiple-origin variables are not dummy variables. Cases were given

18 The self-reported ethnic origin responses used in this section are not without problems. For example, it is unlikely that all respondents perceive the ethnic categories in the same way. This is particularly obvious when we consider the 'Canadian' ethnic category. Almost 8 per cent of the respondents, including a large number of immigrants, identified 'Canadian' as one of their ethnic backgrounds. 
TABLE 5

Selected coefficients from log earnings regressions: detailed ethnicity/immigration groups

\begin{tabular}{|c|c|c|c|c|c|c|}
\hline \multirow[b]{2}{*}{$\begin{array}{l}\text { Aggregate } \\
\text { category }\end{array}$} & \multirow[b]{2}{*}{$\begin{array}{l}\text { Single- or } \\
\text { multiple- }\end{array}$} & \multirow[b]{2}{*}{ Detailed ethnic group } & \multicolumn{2}{|l|}{ MALES } & \multicolumn{2}{|l|}{ FEMALES } \\
\hline & & & $\begin{array}{l}\text { Regression } 5.1 \\
\text { Canadian-born }\end{array}$ & Immigrants & $\begin{array}{l}\text { Regression } 5.2 \\
\text { Canadian-born }\end{array}$ & Immigrants \\
\hline $\begin{array}{l}\text { White } \\
\text { ethnic } \\
\text { origns }\end{array}$ & $\begin{array}{l}\text { Single } \\
\text { ethnic } \\
\text { responses } \\
\text { only }\end{array}$ & $\begin{array}{l}\text { British } \\
\text { French } \\
\text { Canadian } \\
\text { Dutch } \\
\text { German } \\
\text { Polish } \\
\text { Hungarian } \\
\text { Jewish } \\
\text { Spanish } \\
\text { Greek } \\
\text { Italian } \\
\text { Portuguese } \\
\text { Balkan } \\
\text { Ukrainian } \\
\text { Other }\end{array}$ & $\begin{array}{c}\text { Comparison } \\
0.6 \% \\
-1.2 \% \\
0.1 \% \\
0.2 \% \\
0.1 \% \\
-0.2 \% \\
0.5 \% \%^{* *} \\
-0.8 \%^{\dagger} \\
-14.5 \%^{*} \\
-0.3 \%^{*} \\
-0.9 \%^{* *} \\
-10.5 \%^{*} \\
0.2 \% \\
0.1 \%\end{array}$ & $\begin{array}{c}0.0 \% \\
0.0 \% \\
-12.2 \%^{*} \\
-0.5 \%^{* *} \\
-0.3 \% \\
-0.3 \% \\
0.2 \% \\
-0.2 \% \\
-0.9 \%^{*} \\
-17.0 \%^{*} \\
-0.4 \%^{*} \\
0.0 \% \\
-0.8 \%^{*} \\
-0.1 \% \\
-0.4 \%^{* *}\end{array}$ & $\begin{array}{c}\text { Comparison } \\
0.2 \%^{*} \\
-0.2 \% \\
-0.4 \% \\
0.3 \% \%^{* *} \\
0.5 \% \\
0.0 \% \\
0.5 \% \%^{*} \\
-12.3 \% \dagger \\
-14.6 \% \%^{*} \\
0.1 \% \\
0.6 \% \\
0.0 \% \\
0.4 \%^{*} \\
0.5 \%^{*}\end{array}$ & $\begin{array}{c}-0.2 \% \\
-0.7 \% * \\
0.7 \% \\
-0.6 \% \\
-0.3 \% \\
-0.2 \% \\
-0.7 \% \\
-0.6 \% \\
-15.9 \% * \\
0.1 \% \\
-0.1 \% \\
0.0 \% \\
0.5 \% \\
12.4 \% \\
0.3 \%\end{array}$ \\
\hline & $\begin{array}{l}\text { Multiple } \\
\text { ethnic } \\
\text { responses }\end{array}$ & $\begin{array}{l}\text { British with white } \\
\text { French with white } \\
\text { Southern European with white } \\
\text { Central European with white } \\
\text { Other European with white }\end{array}$ & $\begin{array}{c}-0.1 \% \\
-0.4 \% * * \\
0.4 \% \\
-0.1 \% \\
0.9 \%\end{array}$ & $\begin{array}{r}0.0 \% \\
-0.2 \% \\
-0.6 \% \\
-0.1 \% \\
0.3 \%\end{array}$ & $\begin{array}{r}0.0 \% \\
0.3 \% \\
-0.3 \% \\
0.2 \% \\
0.2 \%\end{array}$ & $\begin{array}{r}-0.7 \% \\
15.5 \% \\
14.6 \% \\
0.5 \% \\
-0.8 \%\end{array}$ \\
\hline
\end{tabular}




\begin{tabular}{|c|c|c|c|c|c|c|}
\hline \multirow[b]{2}{*}{$\begin{array}{l}\text { Aggregate } \\
\text { category }\end{array}$} & \multirow[b]{2}{*}{$\begin{array}{l}\text { Single- or } \\
\text { multiple- }\end{array}$} & \multirow[b]{2}{*}{ Detailed ethnic group } & \multicolumn{2}{|l|}{ MALES } & \multicolumn{2}{|l|}{ FEMALES } \\
\hline & & & $\begin{array}{l}\text { Regression } 5.1 \\
\text { Canadian-born }\end{array}$ & Immigrants & $\begin{array}{l}\text { Regression } 5.2 \\
\text { Canadian-born }\end{array}$ & Immigrants \\
\hline $\begin{array}{l}\text { Visible } \\
\text { ethnic } \\
\text { origins }\end{array}$ & $\begin{array}{l}\text { Single } \\
\text { ethnic } \\
\text { responses } \\
\text { only }\end{array}$ & $\begin{array}{l}\text { Arab } \\
\text { Black } \\
\text { Chinese } \\
\text { Filipino } \\
\text { Latin } \\
\text { South Asian } \\
\text { Vietnamese } \\
\text { West Asian } \\
\text { Other Visible }\end{array}$ & $\begin{array}{r}-11.6 \%^{\dagger} \\
-17.4 \%^{*} \\
-12.5 \%^{*} \\
0.5 \%^{\dagger} \\
0.9 \%^{\dagger} \\
0.1 \% \%^{\dagger} \\
28.4 \% \%^{\dagger} \\
-11.9 \%^{\dagger} \\
-0.8 \% *\end{array}$ & $\begin{array}{l}-15.4 \%^{*} \\
-22.2 \%^{*} \\
-1.0 \%^{*} \\
-20.3 \%^{*} \\
-21.4 \%^{*} \\
-14.3 \%^{*} \\
-18.4 \%^{*} \\
-18.6 \%^{*} \\
-14.4 \%^{*}\end{array}$ & $\begin{array}{c}-0.1 \%^{\dagger} \\
0.4 \% \\
0.2 \% \\
-36.1 \% \dagger \\
0.4 \% \dagger \\
0.2 \% \dagger \\
-0.4 \% \dagger \\
10.6 \% \dagger \\
0.2 \%\end{array}$ & $\begin{array}{c}-1.0 \%^{*} \\
-12.4 \%^{*} \\
-0.2 \% \\
-0.9 \%^{*} \\
-0.9 \%^{*} \\
-1.0 \%^{*} \\
-14.8 \%^{*} \\
-10.3 \%^{*} \\
-0.5 \%\end{array}$ \\
\hline Aboriginal & $\begin{array}{l}\text { Multiple } \\
\text { ethnic } \\
\text { responses }\end{array}$ & $\begin{array}{l}\text { Visible Minority with white } \\
\text { British with Visible } \\
\text { French with Visible } \\
\text { Southern European with Visible } \\
\text { Central European with Visible } \\
\text { Other European with Visible } \\
\text { Visible Minority with Visible } \\
\text { Aboriginal }\end{array}$ & $\begin{array}{r}0.9 \% \\
-0.7 \% \%^{\dagger} \\
0.4 \%{ }^{\dagger} \\
-55.5 \%{ }^{\dagger} \\
-44.2 \%{ }^{\dagger *} \\
-0.7 \% \%^{\dagger} \\
15.6 \% \\
-22.5 \%\end{array}$ & $\begin{array}{c}-20.0 \%^{*} \\
-15.3 \%^{* *} \\
0.8 \%^{\dagger} \\
0.6 \%{ }^{\dagger} \\
14.0 \%^{\dagger} \\
-16.2 \%^{\dagger} \\
-17.7 \%^{*} \\
0.4 \%^{\dagger}\end{array}$ & $\begin{array}{r}0.2 \% \\
-0.8 \% \\
21.9 \%{ }^{\dagger} \\
0.7 \%^{\dagger} \\
10.6 \% \dagger \\
14.3 \%{ }^{\dagger} \\
-36.1 \%{ }^{\dagger} \\
-0.1 \%\end{array}$ & $\begin{array}{c}-12.3 \%^{*} \\
-0.4 \% \\
12.3 \%{ }^{\dagger} \\
-20.0 \%^{\dagger} \\
12.5 \%^{\dagger} \\
-48.0 \%^{\dagger *} \\
-10.9 \%^{* *} \\
-146.0 \%^{\dagger *}\end{array}$ \\
\hline origins & Multiple & $\begin{array}{l}\text { Aboriginal with white } \\
\text { Aboriginal with Visible }\end{array}$ & $\begin{array}{r}-16.1 \%^{*} \\
0.4 \%^{\dagger} \\
R^{2}=0.438\end{array}$ & $\begin{array}{c}-48.4 \% \%^{\dagger * *} \\
18.0 \% \dagger \\
n=95,556\end{array}$ & $\begin{array}{l}-17.1 \%^{*} \\
12.9 \%^{\dagger} \\
R^{2}=0.492\end{array}$ & $n=\begin{array}{l}-55.6 \% \%^{\dagger *} \\
-23.0 \%^{\dagger}\end{array}$ \\
\hline
\end{tabular}

SOURCE: 1991 Public Use Microdata File. Individual file.

NOTES

Denotes less than 100 observations in the cell.

${ }^{*}$ Denotes significance at the 5 per cent level.

* Denotes significance at the 10 per cent level.

Both regression control for personal characteristics: household type, official language knowledge, education, potential experience in Canada, and potential experience in six regions outside Canada.

Both regressions include controls for work characteristics: full/part-time, weeks worked, occupation, and industry.

Both regressions include twenty-four foreign place of schooling variables (four levels by six regions of birth)

Both regressions include seventy-eight Detailed Ethnicity/Immigration status variables.

Population age 20-64 not in school full time, with class of worker equal to wage earner. Non-Atlantic CMA residents only. 


\section{Krishna Pendakur and Ravi Pendakur}

fractional values for each ethnic group they reported. Thus, an immigrant who reported British-German-West-Asian background would have a value of one-third in the regression for each of the following immigrant origins: 'British with visible,' 'Central European with visible,' and 'Visible Minority with white.'

Looking first at Canadian-born men with a single ethnic origin (regression 5.1), we see that most estimates for white ethnic groups are not statistically significant, suggesting that the earnings of white single-origin men are not too different from the earnings of British single-origin men for most white ethnic groups. There are some exceptions. Canadian-born Greek and Balkan men face statistically significant earnings differentials of 14.5 per cent and 10.5 per cent, respectively. In the case of visible-minority ethnic groups who are born in Canada, many of the results are hampered by a lack of cases. For those groups with over one hundred observations, however, the earnings gaps are significant for Blacks and Chinese-origin men, with gaps of 17.4 per cent and 12.5 per cent, respectively. Single-origin Aboriginal men also face an earnings gap of 22.5 per cent, compared with Canadian-born British-origin men.

Looking at Canadian-born males with multiple ethnic origins, we see that none of the white multiple-origin variables has large coefficients significantly different from zero. Among the visible minority multiple-origins, only 'visible minority with white' and 'British with visible minority' have large counts (144 and 98, respectively), and neither of these coefficients is significantly different from zero. The results for Aboriginals of multiple origin are strikingly different. People who report Aboriginal and white multiple-ethnic origin face a statistically significant earnings gap of 16.1 per cent.

For white immigrant men, the results are mixed. White immigrants from Northern and Central Europe do not appear to face any substantial earnings penalty. ${ }^{19}$ Greek immigrants, however, as was the case for those born in Canada, face an earnings gap of 17.0 per cent. Visible-minority immigrant men universally face earnings penalties that range from 1.0 per cent for Chinese immigrants to 22.2 per cent for Black immigrants. Excepting the Chinese ethnic group, visibleminority immigrant groups face earnings gaps of over 14 per cent. Latin American and Filipino immigrant men may expect to earn at least 20 per cent less than Canadian-born British men. In comparison with Canadian-born British men, immigrant Vietnamese and West Asian men face earnings gaps of least 18 per cent, and immigrant South Asian and Arab men face earnings gaps of at least 14 per cent.

These earnings gaps for visible-minority immigrants extend to those claiming more than one ethnic origin. Immigrant males claiming a visible-minority origin in combination with a white origin may expect to earn 15 per cent to 20 per cent less than Canadian-born British men. Immigrant men who report multiple ethnic origins all of which are visible-minority origins also face a statistically significant earnings gap of 17.7 per cent. Immigrant men who report multiple ethnic origins all

19 Table 5 shows a large and significant earnings penalty for single-origin immigrants who report 'Canadian' as their ethnic origin. We suspect that these respondents misinterpreted the question. 
of which are white origins, on the other hand, do not face any significant earnings gaps in comparison with Canadian-born British men.

The coefficient estimates given regression 5.2 show that the pattern in earnings differentials for Canadian-born women is different from that we saw for men. As is the case with men, we see a large significant penalty for single-origin Greek women. In contrast to what we saw for men, however, none of the Canadian-born visible-minority single-origin coefficients is significantly different from zero. Even the coefficients on Black and Chinese ethnic origins, which are based on quite large samples, are neither large nor significant. That is, even with a highly disaggregated ethnicity measure, Canadian-born visible-minority women do not face earnings penalties, compared with Canadian-born British women. When we look at Canadian-born women, the visible minority aggregate does not hide heterogeneity among its constituent ethnic groups.

Among the multiple-origin categories, the coefficient for Aboriginal with white reveals a significant and large earnings gap of 17.1 per cent. Non-Aboriginal Canadian-born women with multiple ethnic origins face no earnings differentials in comparison with Canadian-born British women.

Looking now at the coefficients for immigrant ethnic groups, we see that of the white ethnic groups, only Spanish single-origin women face a statistically significant penalty (15.9 per cent). Among visible-minority immigrants, Black, Vietnamese, and West Asian single-origin women experience statistically significant earnings differentials, ranging from 10 per cent to 15 per cent. Notably, however, the earnings of immigrant Chinese, Filipino, Latin American, and South Asian women are not very different from those of Canadian-born British women.

For immigrant women, the multiple-origin coefficients suggest that white women with multiple ethnic origins earn about the same as Canadian-born British women. For immigrant visible-minority immigrant women, on the other hand, we find that women reporting visible minority with white ethnic origins and women reporting visible minority with visible ethnic origins face earnings differentials of 12.3 per cent and 10.9 per cent, respectively.

The disaggregated ethnic group regressions show a great deal of variance. Among men, we find that Canadian-born Greek, Balkan, Black and Chinese men face large and statistically significant earnings penalties ranging from 10.5 per cent to 17.4 per cent in comparison with Canadian-born British men. Among white immigrants, Greek-origin immigrants show an earnings penalty of 17.0 per cent. Similarly, immigrant single-origin men reporting eight of the nine visible-minority origins face earnings penalties ranging from 14 per cent to 22 per cent. Immigrant Chinese-origin immigrant men, however, do not face large earnings gaps. Finally, we see that Aboriginal men, whether of single or multiple origin, face with large and statistically significant earnings gaps.

Among women, we see rather different patterns. Canadian-born Greek and Aboriginal women face large earnings differentials in comparison to Canadian-born British women, but Canadian-born Black and Chinese women do not. Immigrant Spanish, Black, Vietnamese, and West Asian women face significant earnings 
540 Krishna Pendakur and Ravi Pendakur

TABLE 6

Selected coefficients from log earnings regressions, by CMA

\begin{tabular}{|c|c|c|c|c|c|}
\hline Sex & $\begin{array}{l}\text { Immigrant } \\
\text { status }\end{array}$ & $\begin{array}{l}\text { Employment } \\
\text { equity status }\end{array}$ & Montreal & Toronto & Vancouver \\
\hline MALES & Canadian-born & $\begin{array}{l}\text { White } \\
\text { Visible Minority } \\
\text { Aboriginal } \\
\text { White } \\
\text { Visible Minority }\end{array}$ & $\begin{array}{l}\text { Regression } 6.1 \\
\text { Comparison } \\
-16.7 \%^{*} \\
-6.0 \% \\
-7.7 \%^{*} \\
-20.1 \%^{*} \\
n=18,167 \\
R^{2}=0.47\end{array}$ & $\begin{array}{l}\text { Regression } 6.2 \\
\text { Comparison } \\
-8.9 \%^{*} \\
-5.3 \% \\
-0.7 \% \\
-16.7 \% \%^{*} \\
n=22,928 \\
R^{2}=0.40\end{array}$ & $\begin{array}{l}\text { Regression } 6.3 \\
\text { Comparison } \\
-3.6 \% \\
-7.3 \% \%^{* *} \\
-7.4 \%^{*} \\
-12.9 \%^{*} \\
n=9,568 \\
R^{2}=0.45\end{array}$ \\
\hline FEMALES & Canadian-born & $\begin{array}{l}\text { White } \\
\text { Visible Minority } \\
\text { Aboriginal } \\
\text { White } \\
\text { Visible Minority }\end{array}$ & $\begin{array}{l}\text { Regression } 6.4 \\
\text { Comparison } \\
-2.9 \% \\
-3.3 \% \\
-4.0 \% \\
-19.6 \% \%^{*} \\
n=16,872 \\
R^{2}=0.50\end{array}$ & $\begin{array}{c}\text { Regression } 6.5 \\
\text { Comparison } \\
0.8 \% \\
-7.6 \% \\
-0.7 \% \\
-5.9 \% \%^{* *} \\
n=22,306 \\
R^{2}=0.44\end{array}$ & $\begin{array}{l}\text { Regression } 6.6 \\
\text { Comparison } \\
-0.2 \% \\
-9.7 \% \text { * } \\
-3.9 \% \\
-2.4 \% \\
n=8,896 \\
R^{2}=0.46\end{array}$ \\
\hline
\end{tabular}

SOURCE: 1991 Public Use Microdata File. Individual file.

NOTES

${ }^{*}$ Denotes significance at the 5 per cent level.

${ }^{* *}$ Denotes significance at the 10 per cent level.

All regressions control for personal characteristics: household type, official language knowledge, education, potential experience in Canada, and potential experience in six regions outside Canada.

All regressions include controls for work characteristics: full/part-time, weeks worked, occupation, and industry.

All regressions include twenty-four foreign place of schooling variables (four levels by six regions of birth).

Population age 20-64 not in school full time, with class of worker equal to wage earner.

differentials in excess of 10 per cent in comparison with Canadian-born British women, but other ethnic groups - including visible minority groups - do not face large earnings gaps. Among both men and women, it seems that neither whites nor visible minorities are particularly homogeneous in their earnings patterns.

\subsection{Earnings gaps differ across census metropolitan areas}

Table 2 suggests that, among males living in the non-Atlantic CMAs, Canadianborn visible minorities face an 8.2 per cent earnings gap and immigrant visible minorities face a 15.8 per cent earnings gap. However, such an analysis may mask variation across CMAs. In an effort to explore this possibility, table 6 shows the results of separate regressions run for the three largest CMAs (Toronto, Montreal, and Vancouver) for males and females, including all the controls in regressions 3.1 and 3.2 (i.e., including personal characteristics, location, work characteristics, and immigrant place / level of schooling).

Looking first at the results for men (regressions 6.1 to 6.3), we see that Aborig- 
inals face (mildly significant, or insignificant) earnings penalties of approximately 6 per cent in all three CMAs, and that immigrant whites face significant earnings gaps of more than 7 per cent in Vancouver and Montreal. Immigrant visible minorities face statistically significant earnings gaps in all three CMAs, but the gap is smallest in Vancouver, at 12.9 per cent, and largest in Montreal, at 20.1 per cent. Finally, and most strikingly, we see that Canadian-born visible-minority men face statistically significant earnings gaps of 16.7 per cent in Montreal and 8.9 per cent in Toronto, but experience a much smaller (and statistically insignificant) gap of 3.6 per cent in Vancouver.

Among women (regressions 6.4 to 6.6), we see similar patterns. As is the case in table 2 , neither Canadian-born visible-minority women nor immigrant white women face statistically significant earnings gaps in any of the three CMAs. On the other hand, Aboriginal women and immigrant visible-minority women have very different earnings patterns across the three CMAs. Aboriginals face a marginally significant earnings gap of 9.7 per cent in Vancouver and insignificant gaps in Toronto and Montreal. Immigrant visible-minority women face a statistically significant earnings gap of 19.6 per cent in Montreal, a marginally significant gap of 5.9 per cent in Toronto, and no gap in Vancouver.

The above results are rather startling, because they suggest that visible minorities, be they men or women, Canadian born or immigrant, face the largest earnings gaps in Montreal and the smallest in Vancouver. As was noted above, however, within the visible-minority category different ethnic groups have different earnings outcomes, and the three cities have different compositions in terms of detailed ethnic groups. For example, table 5 shows that conditional on characteristics, Chinese men earn more than Black men. Further, in comparison with Vancouver, Toronto and Montreal have proportionally more Black men and fewer Chinese men. Thus, it may be that the differences in earnings gaps across cities shown in table 6 are due to the fact that Montreal has more people in the visible-minority ethnic groups that fare poorly, and Vancouver has more people in visible-minority ethnic groups that fare well.

The ideal way to test for the possibility of composition effects is to run regressions with all seventy-eight detailed ethnicity/immigration variables (as in regressions 5.1 and 5.2) for each city and compare coefficients across cities. Unfortunately, when the sample is divided by city, the cell sizes for detailed ethnic groups are too small for convincing estimation. The hypothesis that composition accounts for all of the differences in basic group earnings across the CMAs is testable, however, with the following simple model.

Let $i$ index workers and $j$ index CMAs $\{$ Vancouver, Toronto, Montreal $\}$.

$\ln Y_{i}$ is the log earnings of person $i, X_{i}^{j}$ is personal characteristics and work characteristics for person $i$ in city $j$, and $\beta^{j}$ is the coefficients on $X_{i}^{j}$.

$D_{i}$ is a vector of 78 detailed ethnicity/immigration status variables, and $\Delta$ is a vector of coefficients on $D_{i}$. $\Delta$ is constant across cities.

$F_{i}^{j}$ is a vector of dummies indicating membership in the five basic groups: 
(1) Canadian-born white; (2) Canadian-born visible minority; (3) Aboriginal;

(4) Immigrant white and (5) Immigrant visible minority. $\Phi^{j}$ is the coefficients on $F_{i}^{j}$, and is estimated for two of the three cities.

$$
\ln Y_{i}=X_{i}^{V} \beta^{V}+X_{i}^{T} \beta^{T}+X_{i}^{M} \beta^{M}+D_{i} \Delta+F_{i}^{V} \Phi^{V}+F_{i}^{M} \Phi^{M} .
$$

If city-specific detailed ethnic composition were the sole cause of the intercity differences in earnings gaps across the five basic groups, then $\Phi^{V}=\Phi^{M}=0$. If, alternatively, Montreal was characterized by all of its visible minority ethnic groups' facing larger earnings gaps than the same ethnic groups in Toronto, then the visible minority element of $\Phi^{M}$ would be significantly less than zero.

Table 7 presents estimated $\Phi^{j}$ coefficients from regressions given by equation (1). In regression 7.1, several of the $\Phi^{j}$ coefficients are statistically significant, and the eight estimated $\Phi^{j}$ coefficients are jointly statistically significant at the 1 per cent level (we reject the hypothesis that $\Phi^{V}=\Phi^{M}=0$ ). In particular, when composition effects are controlled for, as they are in equation (1), Canadian-born men who are members of visible-minority ethnic groups in Montreal face ethnically based earnings gaps 14.9 percentage points larger than those faced by Canadianborn visible-minority men in Toronto. Canadian-born members of visible-minority ethnic groups in Vancouver face ethnically based earnings gaps 7.0 percentage points smaller than those faced by Canadian-born visible-minority men in Toronto. Although the earnings gaps for Canadian-born visible-minority men are smaller in Vancouver than in Toronto, however, the earnings gaps for immigrant white men are 6.0 percentage points larger in Vancouver than in Toronto. If we turn to visibleminority immigrants, we find that immigrant visible-minority men face earnings gaps over 30 percentage points larger in Montreal than in Toronto and Vancouver. These results suggest that, when we evaluate earnings gaps among men, controlling for composition effects does not wash away the intercity differences reported in table 6, and indeed it makes some of these differences look even larger.

Turning to the results for women, we see a rather different picture. None of the $\Phi^{j}$ coefficients in regression 7.2 is individually statistically significant, and the eight $\Phi^{j}$ coefficients are jointly statistically insignificant at the 1 per cent level. Thus, the intercity differences reported in regressions 6.4-6.6 may be due to the different detailed ethnicity/immigration group compositions of the three cities. The moral of table 7 is that for men (but not women), the city-specific differentials given in table 6 are probably not artefacts, owing to the ethnic composition of the populations. Rather, Canadian-born visible-minority men may well experience much larger earnings gaps in Montreal than in either Toronto or Vancouver, and they may face no earnings gap in Vancouver.

\section{Discussion}

Our research shows that among men there are substantial earnings differentials between visible-minority and white workers in the CMAs we examined. Regression 
TABLE 7

Selected coefficients from log earnings regressions: differences aggregate group differentials between CMAs

\begin{tabular}{|c|c|c|c|c|}
\hline Sex & $\begin{array}{l}\text { Immigrant } \\
\text { status }\end{array}$ & $\begin{array}{l}\text { Employment } \\
\text { equity status }\end{array}$ & Montreal & Vancouver \\
\hline \multirow[t]{6}{*}{ MALES } & & & \multicolumn{2}{|c|}{ Regression 7.1} \\
\hline & \multirow[t]{3}{*}{ Canadian-born } & White & Comparison & Comparison \\
\hline & & Visible Minority & $-14.9 \% *$ & $7.0 \%$ ** \\
\hline & & Aboriginal & $-1.3 \%$ & $-3.6 \%$ \\
\hline & \multirow[t]{2}{*}{ Immigrant } & White & $-1.8 \%$ & $-6.0 \% *$ \\
\hline & & Visible Minority & $\begin{array}{l}-31.6 \% * \\
R^{2}=0.441\end{array}$ & $\begin{array}{r}-3.4 \% \\
n=50,663\end{array}$ \\
\hline \multirow[t]{7}{*}{ FEMALES } & & & \multicolumn{2}{|c|}{ Regression 7.2} \\
\hline & \multirow[t]{3}{*}{ Canadian-born } & White & Comparison & Comparison \\
\hline & & Visible Minority & $-5.1 \%$ & $-2.4 \%$ \\
\hline & & Aboriginal & $2.7 \%$ & $-2.5 \%$ \\
\hline & \multirow[t]{3}{*}{ Immigrant } & White & $0.2 \%$ & $-2.4 \%$ \\
\hline & & Visible Minority & $-5.8 \%$ & $0.2 \%$ \\
\hline & & & $R^{2}=0.504$ & $n=48,074$ \\
\hline
\end{tabular}

SOURCE: 1991 Public Use Microdata File. Individual file.

NOTES

${ }^{*}$ Denotes significance at the 5 per cent level.

** Denotes significance at the 10 per cent level.

All regressions control for personal characteristics: household type, official language knowledge, education, potential experience in Canada, and potential experience in six regions outside Canada.

All regressions include controls for work characteristics: full/part-time, weeks worked, occupation, and industry.

All regressions include twenty-four foreign place of schooling variables (four levels by six regions of birth).

Regressions include seventy-eight detailed ethnicity/immigration variables on RHS, as in regressions $5.1-5.2$.

Detailed ethnicity/immigration coefficients are restricted to be the same across cities.

Estimates above are for shift coefficients for groups of detailed ethnicity/immigration categories.

Population age 20-64 not in school full time, with Class of worker equal to wage earner.

analyses and Oaxaca comparisons reveal large differences in mean earnings between groups that cannot be explained by observable characteristics. Conditional on observable individual characteristics, Canadian-born visible-minority and Aboriginal men earn much less than Canadian-born white men, facing earnings differentials of 8.2 per cent and 12.5 per cent, respectively. Further, although immigrant white men earn almost as much as Canadian-born white men, immigrant visible minority men face an earnings gap of 15.8 per cent. In contrast to what we see for men, Canadian-born visible-minority women do not appear to suffer an earnings penalty in comparison with Canadian-born white women. Aboriginal women and immigrant visible-minority women, however, in comparison with Canadian-born white women, face earnings gaps of 6.8 per cent and 9.1 per cent, respectively.

We believe that the 8.2 per cent earnings differential we found between Canadian-born white men and Canadian-born visible-minority men is very im- 


\section{Krishna Pendakur and Ravi Pendakur}

portant. Unlike the gaps between immigrant and Canadian-born workers, which may erode over time as immigrants assimilate into Canadian labour markets, we are not as hopeful that the earnings gaps found within the Canadian-born population will disappear over time. Further, although some earnings differences between immigrants and the Canadian born may be due to differences in preferences, we believe that Canadian-born white workers and Canadian-born visible-minority workers have similar preferences, so that earnings gaps are due primarily to differential opportunities. ${ }^{20}$ Thus, these earnings gaps found among Canadian-born ethnic groups suggest that economic discrimination may play an important role in Canadian labour markets.

We find that, for immigrants, place and level of schooling go a little way to explain the earnings gaps faced by immigrant men and somewhat further to explain the earnings gaps faced by immigrant women, but even when we control for (imputed) foreign education, large earnings gaps remain. Thus, even visible minority immigrants educated in Canada face large earnings gaps, compared with Canadian-born white workers.

Although we find large differentials between whites and visible minorities, our research also points to substantial heterogeneity within these groups. Lumping all the white ethnic groups together or combining all the visible-minority ethnic groups together does not do justice to the complexity of ethnicity-based earnings differentials. We also found that even some men and women of multiple ethnic origin face earnings gaps, suggesting that people of multiple ethnic origin, a rapidly growing segment of Canadian society, need to be treated separately in analysis.

Finally, it seems that ethnicity-based earnings gaps differ greatly across Canada's three largest CMAs. In comparison with Canadian-born white men, Canadian-born visible-minority men face earnings gaps of 16.7 per cent in Montreal, 8.9 per cent in Toronto, and 3.6 per cent in Vancouver. Although Canadian-born visibleminority women do not face statistically significant earnings gaps in the three cities, immigrant visible-minority women face earnings gaps of 19.6 per cent in Montreal, 5.9 per cent in Toronto, and 2.4 per cent in Vancouver.

These findings could have serious implications for the employment equity legislation, immigration, and schooling accreditation policies. First, it appears that despite having Canadian credentials and being socialized in Canada, visible minorities born in Canada face substantial earnings penalties. If these earnings differentials are due to discrimination, it may be an argument for some kind of equalizing policy, such as quotas, comparable worth/pay equity, or hiring policy. The existing federal Employment Equity Legislation is a hiring policy (not a quota policy), which pushes governments to hire designated group members in instances where candi-

20 Culturally rooted differences in preferences across groups may not disappear after one generation in Canada. Sowell (1996) suggests that culturally rooted preferences may be important to labour market outcomes, even for second- and third-generation workers. If these differences in preferences manifest themselves primarily in education, industry, or occupation choice, however, then the results of the present paper (which control for these variables) are still quite suggestive of discriminatory earnings gaps across groups. 
dates have similar qualifications. At best, however, a hiring policy can eliminate only discrimination due to allocation across industries and occupation. Our findings suggest that even after controlling for such differences, substantial earnings gaps between ethnic groups remain.

Regarding immigrants, it is apparent that the earnings differences attributable to place of education differ by sex and across country of birth. Among men, there are large earnings differentials associated with finishing education in Central Europe and Other (including Northern) Europe. However, there is no earnings differential associated with finishing education in Asia and Africa. From a policy standpoint, this suggests that instituting a means of recognizing foreign credentials may help some European immigrant men, but may not affect the earnings of non-European immigrant men - that is, visible-minority immigrant men. Among women, the penalty associated with place of education also varies across country of birth, and such penalties explain a larger proportion of earnings differentials than they do for men. In particular, women who completed their education in Asia or Africa earn 16.4 per cent less than those with the same place of birth who completed their education in Canada. This suggests that a policy aimed at solving credential recognition problems may help visible-minority immigrant women.

The differences we found between men and women and within our broad ethnic groups indicate that we must be very careful in discussions of ethnicity-based earnings gaps and discrimination to specify whom we mean when we talk about the disadvantaged. In particular, employment equity policy that does not differentiate between the situations of visible-minority men and visible-minority women may be inappropriate. Further, we find evidence that the visible-minority category itself may be quite misleading as an indicator for anti-discrimination policy, since it seems to capture some ethnic groups that face earnings gaps and some ethnic groups that do not. Finally, the large differences we found across cities suggest that any national employment equity policy should be consistent with equity and discrimination issues that differ greatly across localities. 


\section{Appendix}

\section{TABLE A1}

Mean log earnings and number of cases, detailed ethnicity/immigration groups, CMA residents

\begin{tabular}{|c|c|c|c|c|c|c|c|c|c|c|}
\hline \multirow{3}{*}{$\begin{array}{l}\text { Visible } \\
\text { minority } \\
\text { status }\end{array}$} & \multirow{3}{*}{$\begin{array}{l}\text { Ethnic } \\
\text { response } \\
\text { type }\end{array}$} & \multirow[b]{3}{*}{ Ethnic group } & \multicolumn{4}{|l|}{ MALES } & \multicolumn{4}{|l|}{ FEMALES } \\
\hline & & & \multicolumn{2}{|c|}{ Canadian by birth } & \multicolumn{2}{|l|}{ Immigrants } & \multicolumn{2}{|c|}{ Canadian by birth } & \multicolumn{2}{|l|}{ Immigrants } \\
\hline & & & $\begin{array}{l}\text { Avg log } \\
\text { earnings (\$) }\end{array}$ & Cases & $\begin{array}{l}\text { Avg log } \\
\text { earnings (\$) }\end{array}$ & Cases & $\begin{array}{l}\text { Avg log } \\
\text { earnings (\$) }\end{array}$ & Cases & $\begin{array}{l}\text { Avg log } \\
\text { earnings (\$) }\end{array}$ & Cases \\
\hline White & Single & British & 10.31 & 21,097 & 10.50 & 4,071 & 9.73 & 19,167 & 9.76 & 3,794 \\
\hline ethnic & ethnic & French & 10.18 & 20,388 & 10.36 & 380 & 9.68 & 18,934 & 9.78 & 339 \\
\hline \multirow[t]{18}{*}{ origns } & responses & Canadian & 10.31 & 3,465 & 10.36 & 154 & 9.74 & 2,824 & 9.93 & 113 \\
\hline & only & Dutch & 10.24 & 712 & 10.40 & 577 & 9.57 & 651 & 9.57 & 404 \\
\hline & & German & 10.26 & 2,389 & 10.43 & 1,068 & 9.67 & 2,131 & 9.68 & 820 \\
\hline & & Polish & 10.34 & 523 & 10.07 & 664 & 9.85 & 515 & 9.60 & 619 \\
\hline & & Hungarian & 10.23 & 221 & 10.37 & 300 & 9.63 & 212 & 9.61 & 201 \\
\hline & & Jewish & 10.52 & 622 & 10.43 & 340 & 9.91 & 747 & 9.77 & 349 \\
\hline & & Spanish & 9.77 & 23 & 9.95 & 357 & 9.58 & 30 & 9.29 & 285 \\
\hline & & Greek & 9.77 & 255 & 9.95 & 554 & 9.52 & 223 & 9.52 & 438 \\
\hline & & Italian & 10.12 & 2,058 & 10.26 & 2,498 & 9.76 & 1,926 & 9.59 & 1,743 \\
\hline & & Portugeuse & 9.91 & 165 & 10.12 & 1,005 & 9.77 & 126 & 9.56 & 804 \\
\hline & & Balkan & 10.07 & 216 & 10.23 & 565 & 9.70 & 194 & 9.73 & 444 \\
\hline & & Ukrainian & 10.30 & 1,593 & 10.39 & 145 & 9.74 & 1,546 & 10.00 & 133 \\
\hline & & Other & 10.26 & 1,133 & 10.37 & 987 & 9.80 & 987 & 9.79 & 815 \\
\hline & Multiple & British with white & 10.23 & 5,998 & 10.41 & 314 & 9.72 & 6,194 & 9.80 & 376 \\
\hline & ethnic & French with white & 10.17 & 2,727 & 10.44 & 121 & 9.71 & 2,964 & 9.89 & 119 \\
\hline & responses & Southern European with white & 10.23 & 604 & 10.19 & 138 & 9.71 & 614 & 9.83 & 117 \\
\hline & & Central European with white & 10.24 & 3,647 & 10.43 & 409 & 9.72 & 3,885 & 9.81 & 445 \\
\hline & & Other European with white & 10.22 & 1,605 & 10.38 & 134 & 9.72 & 1,649 & 9.74 & 140 \\
\hline
\end{tabular}




\begin{tabular}{|c|c|c|c|c|c|c|c|c|c|c|}
\hline \multirow{3}{*}{$\begin{array}{l}\text { Visible } \\
\text { minority } \\
\text { status }\end{array}$} & \multirow{3}{*}{$\begin{array}{l}\text { Ethnic } \\
\text { response } \\
\text { type }\end{array}$} & \multirow[b]{3}{*}{ Ethnic group } & \multicolumn{4}{|l|}{ MALES } & \multicolumn{4}{|l|}{ FEMALES } \\
\hline & & & \multicolumn{2}{|c|}{ Canadian by birth } & \multicolumn{2}{|l|}{ Immigrants } & \multicolumn{2}{|c|}{ Canadian by birth } & \multicolumn{2}{|l|}{ Immigrants } \\
\hline & & & $\begin{array}{l}\text { Avg log } \\
\text { earnings (\$) }\end{array}$ & Cases & $\begin{array}{l}\text { Avg log } \\
\text { earnings (\$) }\end{array}$ & Cases & $\begin{array}{l}\text { Avg log } \\
\text { earnings (\$) }\end{array}$ & Cases & $\begin{array}{l}\text { Avg log } \\
\text { earnings (\$) }\end{array}$ & Cases \\
\hline \multirow{16}{*}{$\begin{array}{l}\text { Visible } \\
\text { ethnic } \\
\text { origins }\end{array}$} & Single & Arab & 9.84 & 58 & 9.91 & 527 & 9.70 & 72 & 9.39 & 314 \\
\hline & ethnic & Black & 9.84 & 118 & 9.95 & 1,277 & 9.68 & 132 & 9.64 & 1,484 \\
\hline & responses & Chinese & 10.07 & 312 & 10.09 & 2,306 & 9.84 & 312 & 9.67 & 2,120 \\
\hline & only & Filipino & 9.36 & 5 & 9.95 & 709 & 9.29 & 8 & 9.78 & 987 \\
\hline & & Latin & 9.74 & 5 & 9.70 & 317 & 10.17 & 3 & 9.38 & 291 \\
\hline & & South Asian & 9.92 & 52 & 10.07 & 2,032 & 9.54 & 62 & 9.56 & 1,668 \\
\hline & & Vietnamese & 10.72 & 2 & 9.81 & 400 & 10.04 & 1 & 9.38 & 279 \\
\hline & & West Asian & 9.63 & 11 & 9.90 & 280 & 9.69 & 15 & 9.48 & 213 \\
\hline & & Other Visible & 10.28 & 195 & 9.91 & 410 & 9.86 & 185 & 9.43 & 397 \\
\hline & Multiple & Visible Minority with white & 9.87 & 144 & 9.95 & 506 & 9.63 & 158 & 9.60 & 479 \\
\hline & ethnic & British with Visible & 10.05 & 98 & 10.06 & 121 & 9.66 & 100 & 9.72 & 131 \\
\hline & responses & French with Visible & 10.05 & 36 & 10.07 & 22 & 9.72 & 32 & 9.86 & 27 \\
\hline & & Southern European with Visible & 9.86 & 11 & 10.36 & 38 & 9.79 & 11 & 9.75 & 36 \\
\hline & & Central European with Visible & 9.85 & 35 & 10.24 & 31 & 9.58 & 47 & 9.74 & 46 \\
\hline & & Other European with Visible & 10.13 & 22 & 10.02 & 43 & 9.60 & 26 & 9.53 & 43 \\
\hline & & Visible Minority with Visible & 9.87 & 20 & 10.03 & 143 & 9.51 & 16 & 9.68 & 148 \\
\hline \multirow{3}{*}{$\begin{array}{l}\text { Aboriginal } \\
\text { origins }\end{array}$} & Single & Aboriginal & 9.63 & 458 & 10.95 & 1 & 9.42 & 469 & 8.18 & 7 \\
\hline & Multiple & Aboriginal with white & 9.99 & 560 & 10.03 & 13 & 9.55 & 569 & 9.33 & 17 \\
\hline & & Aboriginal with Visible & 9.89 & 15 & 10.29 & 1 & 9.59 & 17 & 9.44 & 2 \\
\hline Total & & & & 71,598 & & 23,958 & & 67,754 & & 21,187 \\
\hline
\end{tabular}

SOURCE: 1991 Public Use Microdata File. Individual file.

\section{NOTES}

Population age 20-64 not in school full time, with Class of worker equal to wage earner.

Residents of non-Atlantic CMAs only. 
548 Krishna Pendakur and Ravi Pendakur

\section{References}

Abella, Rosalie S. (1984) Report of the Commission on Equality in Employment (Ottawa: Royal Commission on Equality in Employment)

Canada (1996) Canadian Human Rights Act. Statutes of Canada, c.14, s.1 (Ottawa: Government of Canada)

- (1997) The Employment Equity Act. Statutes of Canada (Ottawa: Government of Canada)

Akbari, A. (1992a) Economics of Immigration and Racial Discrimination: A Literature Survey (1970-1989) (Ottawa: Multiculturalism and Citizenship)

- (1992b) Ethnicity and Earnings Discrimination in Canadian Labour Markets: Some Evidence from the 1986 Census (Ottawa: Multiculturalism and Citizenship)

Baker, M., and D. Benjamin (1997) 'Ethnicity, foreign birth and earnings: a Canada/US comparison,' in Transition and Structural Change in the North American Labour Market, ed. M.G. Abbott, C.M. Beach, and R.P. Chaykowski (Kingston: IRC Press, Industrial Relations Centre, Queen's University)

Beach, C.M., and C. Worswick (1993) 'Is there a double-negative effect on the earnings of immigrant women?' Canadian Public Policy 19, 36-53

Bloom, D., G. Grenier, and M. Gunderson (1994) 'The changing labor market position of Canadian immigrants,' NBER Working Paper No. 4672

Christofides, L., and R. Swidinsky (1994) 'Wage determination by gender and visible minority status: evidence from the 1989 LMAS,' Canadian Public Policy 20, 34-51

Cotton, Jeremiah (1988) 'On the decomposition of wage differentials.' Review of Economics and Statistics 70, 236-43

George, P., and P. Kuhn (1994) 'The size and structure of native-white differentials in Canada,' Canadian Journal of Economics 27, 20-42

Gera, S., and G. Grenier (1994) 'Interindustry wage differentials and efficiency wages: some Canadian evidence,' Canadian Journal of Economics 27, 81-100

Howland, J., and C. Sakellariou (1993) 'Wage discrimination, occupational segregation and visible minorites in Canada,' Applied Economics 25, 1413-22

Kelly, K. (1995) 'Visible minorities: a diverse group,' Canadian Social Trends 37, 2-8

Kidd, M., and M. Shannon (1994) 'An update and extension of the Canadian evidence on gender wage differentials,' Canadian Journal of Economics 27, 918-38

McDade, K. (1988) Barriers to Recognition of the Credentials of Immigrants in Canada (Ottawa: Institute for Research in Public Policy)

Miller, Paul W. (1987) 'Gender differences in observed and offered wages in Canada, 1980,' Canadian Journal of Economics 20, 225-44

Mincer, J. (1974) Schooling, Experience, and Earnings (New York: Columbia University Press)

Oaxaca, R.L. (1973) 'Male-female wage differentials in urban labor markets,' International Economic Review 14, 693-709

Porter, J. (1965) The Vertical Mosaic (Toronto: Univerisity of Toronto Press)

Portes, A., and A. Stepick (1993) City on the Edge: The Transformation of Miami (Berkeley, CA: University of California Press)

daSilva, A. (1992) 'Earnings of immigrants: a comparative analysis,' Economic Council of Canada Working Paper Series

daSilva, A., and C. Dougherty (1996) Discrimination against Visible Minority Men (Ottawa: Applied Research Branch, Human Resources and Development Canada)

Sowell, Thomas (1996) Migrations and Cultures: A World View (New York: Basic Books)

Stelcner, M., and N. Kyriazis (1995) 'An empirical analysis of earnings among ethnic groups in Canada,' International Journal of Contemporary Sociology 32, 41-79 